\section{Commentary: Stentless root takes root in real world}

\author{
Paul Stelzer, MD
}

Dagnegård and colleagues ${ }^{1}$ present the largest study to date of aortic root replacement using a stentless porcine root (Freestyle, Medtronic, Minneapolis, Minn)_-1008 patients had 1030 operations. Having been 1 of only 2 principal investigators in the initial worldwide investigation (begun in 1992) to consistently use full root method of implantation, ${ }^{2}$ it is gratifying to see the technique validated in a wide variety of root pathologies. Including small-to medium-size programs gives a "real-world" context, but each center is in truth a regional aortic surgery referral center. National registries allowed complete capture of survival data but did not provide echo information, which, respectively, are major strengths and weaknesses. Median follow-up was 5 years but ranged up to 17 years. A significant difference in survival is demonstrated between elective and nonelective cases even when the first 3 months are taken out of the picture. The authors correctly conclude that difference in outcomes is not a function of the prosthesis but of patient disease and patient characteristics. Safety was demonstrated across a broad range of aortic root disease, with particularly low risk for elective patients with aortic root aneurysm.

Survival of elective patients at 10 years was equivalent to an age- and sex-matched normal Danish population and superior to survival of patients with mechanical and animal tissue valves. I believe the reason for this is the normal anatomical structure, which minimizes obstructive components. Anticalcification treatment and low-pressure fixation may also contribute to durability. It has been my experience that this device as a full root replacement allows a larger size (by 2-4 $\mathrm{mm}$ ) than a standard stented valve. Furthermore, the labeled size is essentially the

\footnotetext{
From the Department of Cardiovascular Surgery, Icahn School of Medicine at Mount Sinai, New York, NY.

Disclosures: The author reported no conflicts of interest.

The Journal policy requires editors and reviewers to disclose conflicts of interest and to decline handling or reviewing manuscripts for which they may have a conflict of interest. The editors and reviewers of this article have no conflicts of interest.

Received for publication July 17, 2021; revisions received July 17, 2021; accepted for publication July 19, 2021; available ahead of print July 28, 2021.

Address for reprints: Paul Stelzer, MD, Department of Cardiovascular Surgery, Icahn School of Medicine at Mount Sinai, 1190 Fifth Ave, New York, NY 10029 (E-mail: Paul.Stelzer@mountsinai.org).

J Thorac Cardiovasc Surg 2022;164:1725

$0022-5223 / \$ 36.00$

Copyright (c) 2021 by The American Association for Thoracic Surgery

https://doi.org/10.1016/j.jtcvs.2021.07.032
}

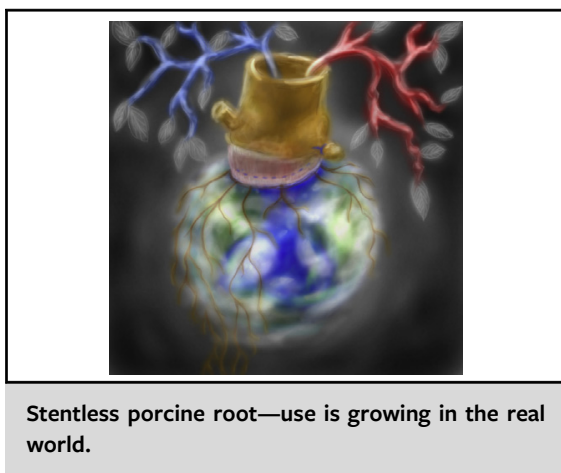

CENTRAL MESSAGE

Stentless porcine root replacement is safe, effective, and widely applicable.

internal diameter of the new root instead of the outside, as seen with stented valve. Mean gradients were in single digits for all but the $19-\mathrm{mm}$ roots. The largest valve $(27 \mathrm{~mm})$ consistently provided valve areas in excess of $2 \mathrm{~cm}^{2}$. (My own experience surprisingly had more than two-thirds of patients getting a $27-\mathrm{mm}$ root until the 29 became available.)

As the authors point out, caution is needed in the setting of small aortic roots. The stentless root is a great alternative in this setting and a larger valve area can always be achieved, but the coronary "button" reimplantation is less forgiving in the small root, so this must be done with great care to avoid kinking or compression issues. Too big a device can become a problem.

The real issue is the fact that replacing the aortic root is still a very uncommon procedure in the vast majority of hospitals that perform cardiac surgery. The greatest-risk patients like those with endocarditis and acute dissection are not easily transferred to distant centers. The stentless porcine device has the advantage of being "on-the-shelf" in all sizes, which is an advantage over aortic homograft. This study should encourage more centers to expand the use of this technique but to focus the experience as much as possible for best results.

\section{References}

1. Dagnegård HH, Bekke K, Kolseth SM, Glaser N, Wallén C, El-Hamamsy I, et al Survival after aortic root replacement with a stentless xenograft is determined by patient characteristics. J Thorac Cardiovasc Surg. 2022;164:1712-24.e10.

2. Kon ND, Cordell AR, Adair SM, Doggins JE, Kitzman DW. Aortic root replacement with the Freestyle stentless porcine aortic root bioprosthesis. Ann Thorac Surg. 1999;67:1609-16. 